\title{
ESTABLISHMENT OF EFFECTIVE TECHNOLOGICAL PARAMETERS AT THE CONTOUR BLASTING OF BOREHOLE CHARGES
}

\section{O. Frolov, T. Kosenko, Yu. Maltseva}

National Technical University of Ukraine "Igor Sikorsky Kyiv Polytechnic Institute" vul. Borschagivska, 115, Kiev, 03056, Ukraine. E-mail: frolov@ geobud.kiev.ua

Purpose. The purpose of these studies is to determine effective parameters blasting by presplitting method of borehole charges. Methodology. To solve research tasks, a comprehensive research methodology has been applied that consists of the analysis and generalization of previous scientific studies on the implementation of blasting by presplitting method, theoretical studies on achieving effective conditions for interaction of pre-split borehole charges, as well as tests of developed designs of pre-split charges in industrial conditions. The analysis of contour blasting methods and calculation of contour blasting parameters shows that, for effective destruction of rock masses, it is necessary to create conditions, in which directional blasting energy flows will be formed in the rock mass due to the total shock wave impulse. Results. Based on results of the studies, the dependence of the average linear mass of the explosive charge on the distance between boreholes that ensures the development of a directed network of fractures between pre-split charges upon their blasting has been obtained. It is established that each type of the design of the pre-split borehole charge that is characterized by the averaged linear mass corresponds to the optimal distance between pre-split boreholes. It is shown that the most optimal distance between the pre-split borehole charges the ensures the development of a fracture network for various rocks varies from $1,5 \mathrm{~m}$ for quartz-mica slate to $4,2 \mathrm{~m}$ for weathered ferruginous quartz. In this case, the explosive charge should be $100 \mathrm{~mm}$ in diameter. Originality. Proceeding from, the subject of these studies is established technological parameters of blasting by presplitting method that ensure formation of energy flows of the borehole charge blasting to obtain design bank slopes. Practical value. A design for a network borehole charge, which implies that an explosive is placed uniformly in a polymer shell along its length and held in a vertical position along the borehole axis. The proposed technology for the formation of pre-split charges of explosives has been successfully tested in industrial conditions. References 10, tables 0 , figures 4.

Key words: blasting, borehole, contour, parameter, charge, rock, slope.

\section{ВСТАНОВЛЕННЯ ЕФЕКТИВНИХ ТЕХНОЛОГІЧНИХ ПАРАМЕТРІВ КОНТУРНОГО ПІДРИВАННЯ СВЕРДЛОВИННИХ ЗАРЯДІВ \\ О. О. Фролов, Т. В. Косенко, Ю. С. Мальцева}

Національний технічний університет України «КПІ ім. Ігоря Сікорського» вул. Борщагівська, 115, м. Київ, 03056, Україна. E-mail: frolov@ geobud.kiev.ua

Наведено дослідження, спрямовані на розробку методів управління процесом руйнування гірських порід при контурному підриванні, оскільки при проведенні таких робіт в скельних масивах виникають проблеми, пов'язані з вибором

Сучасні ресурсоенергозберігаючі технології гірничого виробництва. Випуск 1/2018(21). 


\section{ЗАСТОСУВАННЯ ПІДРИВНИХ РОБІТ НА ДЕННІЙ ПОВЕРХНІ}

Й У ПІДЗЕМНИХ УМОВАХ

раціональних параметрів контурного підривання і обгрунтуванням застосування найбільш ефективного способу його реалізації. Для вирішення науководослідних завдань застосовано комплексну методологію досліджень, яка складається з аналізу і узагальнення попередніх наукових досліджень 3 питань реалізації контурного підривання, теоретичних досліджень по досягненню ефективних умов взаємодії енергетичних потоків вибухів контурних свердловинних зарядів, а також експериментальних випробувань розроблених конструкцій контурних зарядів в промислових умовах. За результатами проведених досліджень отримано залежність усередненої лінійної маси заряду вибухової речовини від відстані між свердловинами, яка забезпечує розвиток спрямованої мережі тріщин між зарядами контурного ряду при їх підриванні. Встановлено, що кожному типу конструкції контурного свердловинного заряду, який характеризується усередненої лінійної масою, відповідає оптимальне значення відстані між контурними свердловинами. Показано, що при діаметрі заряду 100 мм найбільш оптимальна відстань між свердловинами контурного ряду змінюється від 1,5 м для сланцю кварц-слюдистого до 4,2 м для кварцу залозистого вивітреного. Запропоновано конструкцію контурного заряду, в якій вибухова речовина розміщується в полімерній оболонці рівномірно по його довжині і утримується у вертикальному положенні по осі свердловини. Запропонована технологія формування контурних свердловинних зарядів вибухових речовин успішно випробувана в промислових умовах.

Ключові слова: вибух, свердловина, контур, параметр, заряд, порода, уступ.

PROBLEM STATEMENT. One of the negative consequences in carrying out mass explosions in open pits is the back-break. This leads to a decrease in stability of bank slopes, reduction in angles of bank slopes in comparison with the project and requires additional costs for artificial strengthening of banks or cutback in order to restore transport berms on the ultimate pit and considerably complicates subsequent drilling and blasting operations. To eliminate these drawbacks, presplitting blasting method that due to the creation of a shielding plane makes it possible to obtain a relatively flat and stable surface of the bank and reduce the amount of destruction behind the final boundary is used [1-3].

At present, a significant progress has been achieved in the field of application of contour blasting in open pit mining. However, a number of key issues related to the choice of rational parameters of contour blasting, predictive estimate and choice of methods that allow increasing the efficiency of the formation of the angles of bank slopes has not been solved $[4,5]$.

In particular, reference parameters of contour borehole charges obtained as a result of the generalization of actual indices are given in work [6]. It is recommended to take the borehole diameter within the range from $100 \mathrm{~mm}$ to $150 \mathrm{~mm}$. At the same time, it is noted that positive results of contour blasting can be achieved even with a larger borehole diameter.

Сучасні ресурсоенергозберігаючі технології гірничого виробництва. Випуск 1/2018(21). 
In most cases, the justification of the method of contour blasting in open pits consists in choosing a rational design of borehole charges with a fixed distance between them or in the optimal arrangement of contour boreholes of different diameters with a reduced content of the explosive in borehole charges [7]. The properties of the rock mass to be destroyed are generally accounted indirectly, based on production experience of the mining enterprise.

Analysis the above scientific studies has shown that the existing methods for the determination of contour blasting parameters offer general dependences that only establish the ratio of the main parameters of contour charges (borehole diameter, distance between boreholes, charge mass) taking into account certain characteristics of rocks. The choice of rational parameters of contour blasting for specific mining and geological conditions remains completely unrevealed.

The purpose of these studies is to determine effective parameters blasting by presplitting method of borehole charges.

MATERIAL AND RESULTS. Theoretical studies of the interaction of blasting energy flows. As a result of the blasting in the mass, a stress state is formed around the cylindrical cavity. Since when blasting contour charges, we need to create the minimum permissible stress state of the rock mass in the middle of the well location line, then when choosing the parameters of drilling and blasting operations, it is necessary to proceed from the condition of ensuring the process of rock destruction in the interval between charges with a given width $\Delta$.

With the simultaneous explosion of adjacent cylindrical charges of explosives, the displacement of the rock mass at points lying along the $\mathrm{AB}$ line (Figure 1) in the direction radial from the charge is impossible. Therefore, to estimate the state of stress at point $\mathrm{B}$, we consider azimuthal component of stresses $\sigma_{\theta}{ }^{B}=0$. Tangential stresses at a system of rectangular coordinates $\tau_{x y}^{B}$ at point $B$ caused by blasting of adjacent borehole charges are equal in magnitude, but they are reverse in direction, and their resultant value will be $\tau^{B}{ }_{x y}=0$. As a result of summing radial stresses $\sigma_{r}$ at point $\mathrm{B}$, equations will be as follows [8]:

$$
\begin{aligned}
\sigma_{x}^{B} & =2 \sigma_{r} \cos ^{2} \theta ; \\
\sigma_{y}^{B} & =2 \sigma_{r} \sin ^{2} \theta ; \\
\tau_{x y}^{B} & =0,
\end{aligned}
$$

where $\sin \theta \mathrm{i} \cos \theta$ are parameters that are determined by rations:

$$
\cos ^{2} \theta=\frac{a^{2}}{a^{2}+\Delta^{2}} ; \sin ^{2} \theta=\frac{\Delta^{2}}{a^{2}+\Delta^{2}}
$$

Сучасні ресурсоенергозберігаючі технології гірничого виробництва. Випуск 1/2018(21). 


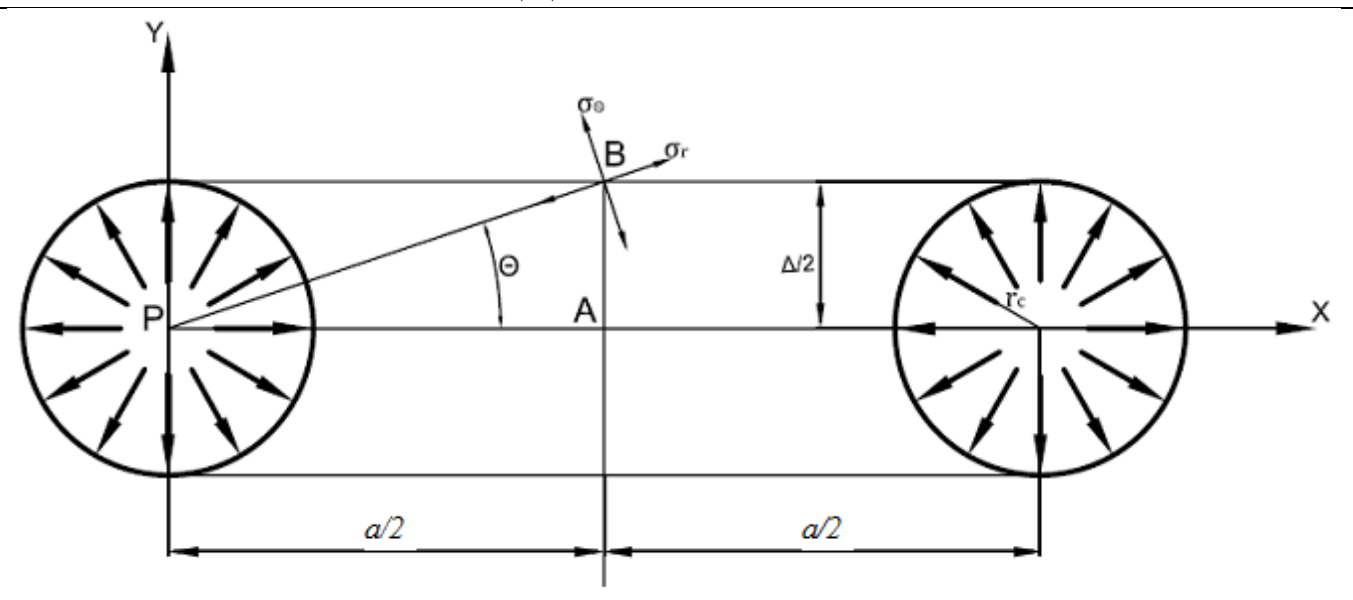

Figure 1 - Scheme for the determination of blasting by presplitting method

When the rock mass is destroyed in the contour of the slope, the tensile stresses $\sigma_{r}$, which at the point $\mathrm{B}$ are determined by the dependence:

$$
\sigma_{p}^{B}=\sigma_{y}^{B}-v \sigma_{x}^{B},
$$

where $v$ is the Poisson's ratio.

Radial stresses resulted from the blasting of a single cylindrical charge are calculated by formula:

$$
\sigma_{r}=P \cdot f_{p}(r) \cdot f_{3}(r)
$$

where $P$ - pressure of detonation products on the borehole walls, $\mathrm{Pa} ; f_{p}(r)=\left(r_{c} / r\right)^{0,5}$ - function of the geometric divergence of cylindrical waves and distance; $f_{3}(r)=\exp \left(-\alpha r / r_{c}\right)-$ absorption function that takes into account the loss of stress waves; $a$-distance between boreholes, $\mathrm{m} ; r_{c}$ - borehole radius, $\mathrm{m} ; r$-current distance to the charge, $\mathrm{m} ; \alpha-$ absorption coefficient.

Let's substitute in formula (3) value $\sigma_{y}{ }^{B}$ and $\sigma_{x}{ }^{B}$ (formula (1)) by taking into account (2) and value $\sigma_{r} \mathrm{c}(4)$ at

$$
r=\frac{1}{2} \sqrt{a^{2}+\Delta^{2}}
$$

and we obtain equation

$$
\sigma_{\mathrm{p}}^{B}=2 P \sqrt{d_{c}} \frac{v a^{2}-\Delta^{2}}{\sqrt[4]{\left(a^{2}+\Delta^{2}\right)^{5}}} \exp \left[-\alpha \frac{\sqrt{a^{2}+\Delta^{2}}}{d_{c}}\right] .
$$

Due to the fact that the density of the explosive charge in the pre-split boreholes is low, the pressure of detonation products on the borehole walls does not usually exceed $200 \mathrm{MPa}$ and is calculated as follows: 


$$
P=\frac{4 q \omega(\gamma-1) \eta}{\pi d_{\mathrm{c}}^{2}}
$$

where $q$ - linear mass of the charge, $\mathrm{kg} / \mathrm{m} ; \omega$ - specific energy of explosives, $\mathrm{J} / \mathrm{kg} ; \gamma-$ isentropic exponent: $\gamma=1,45 ; \eta$ - energy loss factor; $d_{\mathrm{c}}$ - borehole diameter, $\mathrm{m}$.

Since the main destructive stress in blasting by presplitting method is the tensile stress that, in the ideal case, should create a separation fracture, in this case, the condition for the destruction of the rock mass are:

$$
\sigma_{\mathrm{p}}^{B} \geq \sigma_{\text {кр }}
$$

where $\sigma_{\text {кр }}-$ ultimate tensile strength of rock, $\mathrm{Pa}$.

In accordance with the basic principles of mechanics of fracturing the continuous medium, the critical stress value at two-dimensional state of stress for separation fractures is determined based on the expression:

$$
\sigma_{\mathrm{p}}=\frac{\sqrt{2} K_{c}}{\sqrt{\pi a}}
$$

where $K_{c}$ - critical factor of stress intensity.

Thus, using formulas (6), (7), (9) and the condition for the destruction of the rock mass, we determine the necessary linear mass of the charge that ensures the condition for the fracture development between pre-split boreholes:

$$
q=\frac{\sqrt{2 \pi}}{4} \frac{K_{\mathrm{c}}}{\omega \eta \sqrt{a}} \sqrt{d_{c}^{3}} \frac{\sqrt[4]{\left(a^{2}+\Delta^{2}\right)^{5}}}{v a^{2}-\Delta^{2}} \exp \left[\alpha \frac{\sqrt{a^{2}+\Delta^{2}}}{d_{c}}\right] .
$$

The analysis of Eq. (10) shows that there is a definite dependence of the linear mass of the pre-split charge of the explosive $q$ on the distance between pre-split charges $a$ at established properties of the rock mass.

Calculations have been made for rocks that are represented within the open pit of the Poltava Mining and Processing Combined Works to establish a graphical relationship between $q$ and $a$ under the following parameters of the pre-split borehole charge: borehole diameter $-d_{\mathrm{c}}=0,25 \mathrm{~m}$; specific energy of gramonite blasting 79/21 $\omega=4285 \mathrm{~kJ} / \mathrm{kg}$; energy loss factor $-\eta=0,7$. Indicators characterizing physical and mechanical properties of rocks are given in master's thesis Britvina Yu.O.

Figures 2 and 3 show graphical dependences of the change in the linear mass of charge $q$ on the distance between the pre-split boreholes $a$ during the destruction of rocks of different hardness that are located within the open pit. 


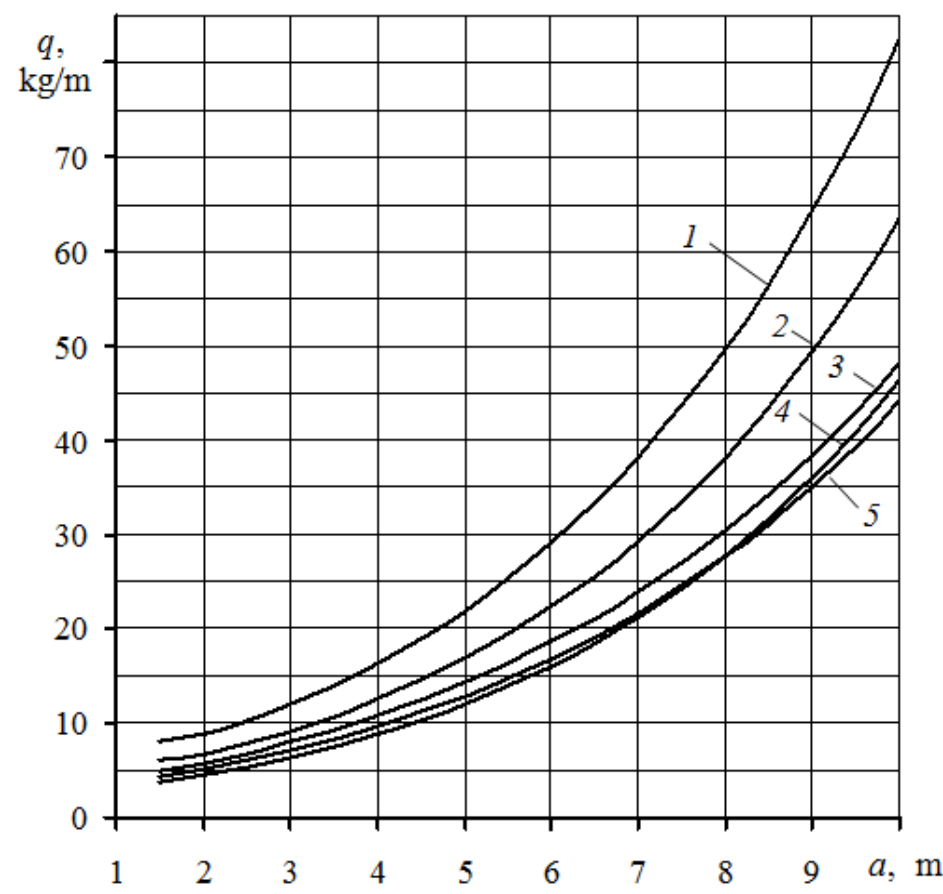

Figure 2 - Dependence of the linear mass of the charge $q$ on the distance between the pre-split boreholes $a$ during the destruction of rocks:

1 - quartz-biotite slate; 2 - quartz-mica slate; 3 - magnetite quartzite;

4 - buck quartz; 5 - cumingtonite-magnetite quartz

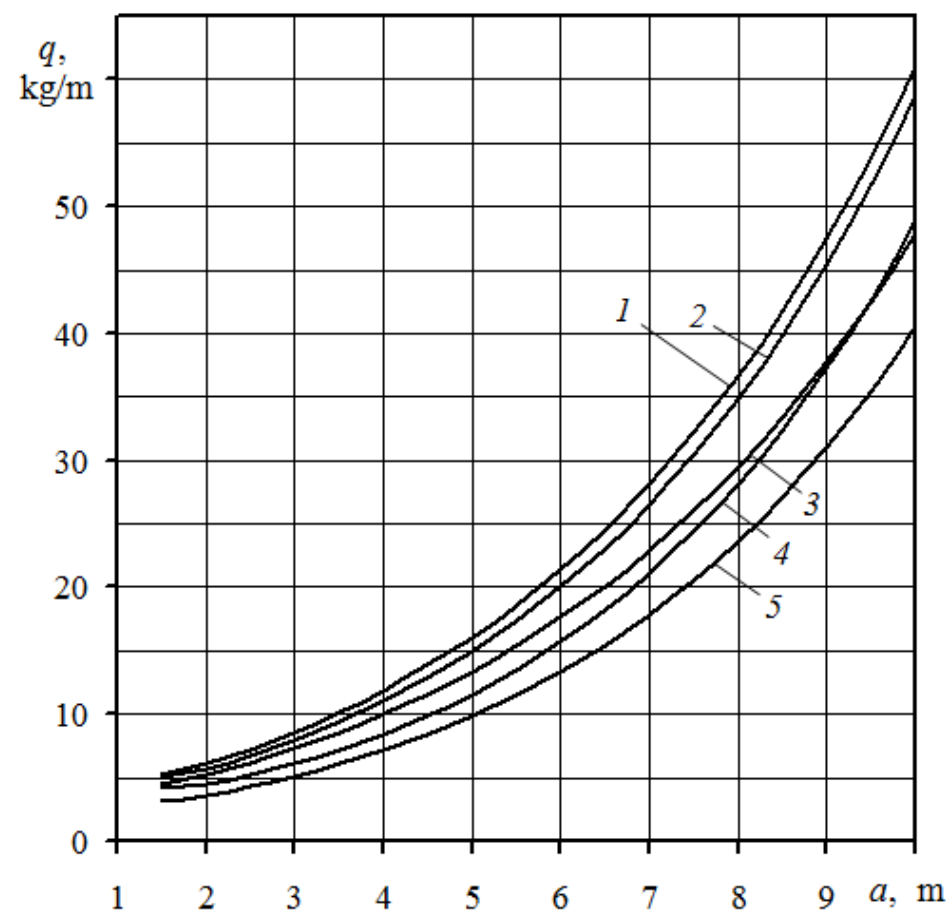

Figure 3 - Dependence of the linear mass of the charge $q$ on the distance between the pre-split boreholes $a$ during the destruction of rocks: 1 - plagiogranite, migmatite; 2 - weathered shale; 3 - amphibolites; 4 - granitoids; 5 - weathered ferruginous quartz 
As a result of the analysis of dependencies, it was established that blasting in the quartz-biotite shales (Fig. 2, dependence 1) with gramonite 79/21 at a distance of $3,0 \mathrm{~m}$ from each other, the linear mass of the charge should be $12 \mathrm{~kg}$. If the work is carried out in the quartz-mica shales, the linear mass of the charge decreases to $9 \mathrm{~kg}$ (Fig. 2, dependence 2). Thus, to create a directed network of fractures with a distance between the boreholes of $3 \mathrm{~m}$, the greatest amount of explosive per $1 \mathrm{~m}$ of charge required for the destruction of quartz-biotite shales is $12 \mathrm{~kg}$, the smallest amount for weathered ferruginous quartz is $5 \mathrm{~kg}$ (Figure 3 , dependence 5).

In general, it should be noted that with the increase in the distance between presplit charges, the linear mass increases in the parabolic dependence. The nature of the change in established dependencies for different types of rocks is not the same, since some of them intersect between themselves (see Fig. 2, 3).

To ensure the stability of detonation, the contour well is proposed to be formed by placing it in a polymeric shell and holding the charge column in an upright position. For this purpose, the technology of loading industrial explosives into the sleeve feed device is used [9]. Fig. 4 shows the design of the charge with the use of the sleeve feed device with the help of which charges are formed diameters 127-200 $\mathrm{mm}$ [10].

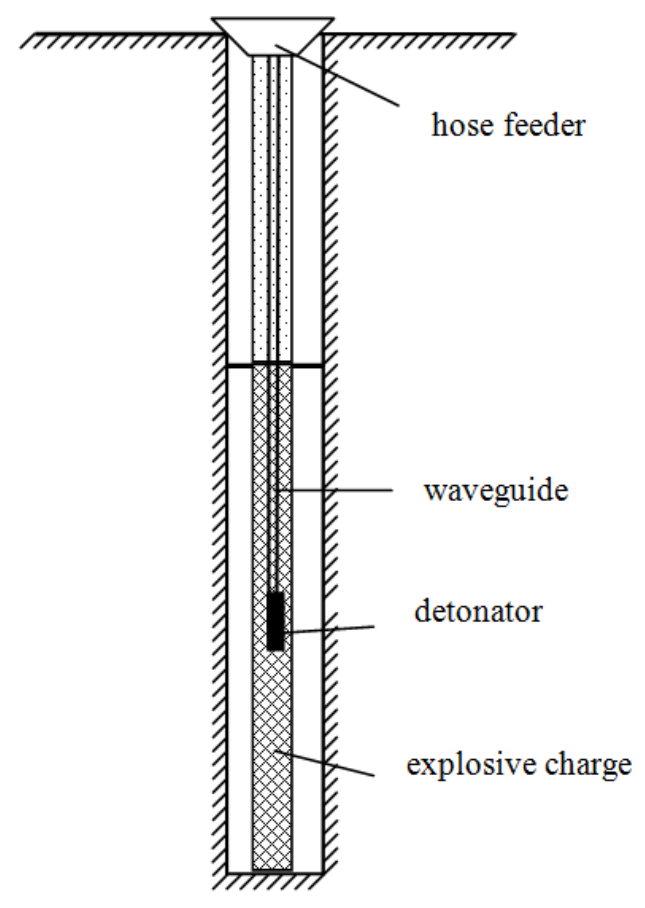

Figure 4 - Design of the borehole charge with the use of the sleeve feed device

The above technology has been successfully tested in industrial conditions. In presplitting boreholes with a diameter of $250 \mathrm{~mm}$, the charge with a diameter of $127 \mathrm{~mm}$ is placed in the polymer sleeve. Under such conditions, the consumption of bulk explosives per $1 \mathrm{~m}$ of the borehole charge was $13 \mathrm{~kg}$ and it was $19 \mathrm{~kg}$ emulsion explosives. This design ensured the uniformity of the explosive distribution along the length, location of the charge along the borehole axis and technology of the charge formation in the borehole with any level of water cut.

Сучасні ресурсоенергозберігаючі технології гірничого виробництва. Випуск 1/2018(21). 
CONCLUSIONS. Based on the results of the conducted studies:

1. It has been established that each type of the pre-split borehole charge design that is characterized by the averaged linear mass corresponds to the optimal distance between pre-split boreholes.

2. A design for a network borehole charge, which implies that an explosive is placed uniformly in a polymer shell along its length and held in a vertical position along the borehole axis. The mentioned technology for the formation of pre-split borehole charges has been successfully tested in industrial conditions.

3. A promising direction of further scientific developments are theoretical and experimental studies of the effect of the natural fracture pattern of the rock mass on parameters of blasting by presplitting method.

\section{REFERENCES}

1. Vorobyov, V.V., Protsenko, V.Ye., Kostin, V.V. (2011), "Determination of optimal charge parameters for contour blasting", Zbirnyk "Suchasny resursoenergozberigauchi tehnolohii hirnychoho vyrobnytstva" of Kremenchuk Mikhailo Ostrohradskyi National University, vol. 3, no. 8, pp. 39-43.

2. Garkusha, I.P., Kurynnoy, V.P., Kogushniy, V.D. (1999), "Justification of the parameters of the hole charge of the explosive for contour blasting", Naukovyy visnyk Natsyonal'noho hirnychoho universytetu, no. 3, pp. 88-89.

3. Etkin, M.B., Azarkovich, A.Ye. (2004), Vzryivnyie rabotyi v energeticheskom $i$ promyishlennom stroitelstve: nauchno-prakticheskoe rukovodstvo [Explosive work in energy and industrial construction: scientific and practical guidance], Izdatelstvo Moskovskogo gornogo universiteta, Moscow, Russia.

4. Ratushnyiy, V.M. (2010), "Perfection of the main parameters of the method of contour blasting during the discharge of working benches in the sides of the quarries of the mining and processing enterprises of Krivbass", Razrabotka rudnyih mestorozhdeniy: nauch.-tehn. sbornik of Kryvoriz'koho universytetu, no. 93, pp. 3235.

5. Paramonov, G.P., Shalaev, M.S. (2010), "To the problem of increasing the efficiency of the screening gap due to the choice of the rational design of the charge", Sbornik «Vzryivnoe delo», no. 103/60, pp. 190-199.

6. Zagoruiko, Ye.A., Kosenko, T.V., Frolov, O.O. (2008), "The analysis of methods of definition of parameters of planimetric detonation for formation of constant barriers of quarry during development of the rocks", Visnyk Zhytomyrs'koho derzhavnoho tekhnolohichnoho universytetu, no. 1(44), pp. 144-147.

7. Fokin, V.A., Tarasov, G.Ye., Togunov, M.B., Danilkin, A.A., Shytov, Yu.A. (2007), "Substantiation of rational parameters of blasting of contour blocks with application of boreholes with reduced diameter", Vzryivnoe delo, no. 97/54, pp. 32-39.

8. Zagoruiko, Ye.A., Kosenko, T.V., Frolov, O.O. (2009), "Establishing patterns between the properties of the rock massif and contouring explosion parameters on condition of the shield crack formation", Visnyk KTU tekhnichnoho universytetu, no. 23, pp. 190-193.

Сучасні ресурсоенергозберігаючі технології гірничого виробництва. Випуск 1/2018(21). 
9. Prokopenko, V.S., Lotous, K.V. (2006), Vzryivanie gornyih porod skvazhinnyimi zaryadami vzryivchatyih veschestv $v$ rukavah [Blasting of rocks by borehole explosive charges in sleeves], Politechnica, Kiyv, Ukraine.

10. Prokopenko, V.S. (2010), Razrushenie gornyih porod skvazhinnyimi zaryadami vzryivchatyih veschestv $v$ rukavah [Destruction of rocks by borehole explosive charges in sleeves], NTUU "KPI", Kiyv, Ukraine.

\section{УСТАНОВЛЕНИЕ ЭФФЕКТИВНЫХ ТЕХНОЛОГИЧЕСКИХ ПАРАМЕТРОВ КОНТУРНОГО ВЗРЫВАНИЯ СКВАЖИННЫХ ЗАРЯДОВ}

\section{А. А. Фролов, Т. В. Косенко, Ю. С. Мальцева}

Национальный технический университет Украины

«КПИ им. Игоря Сикорского»

ул. Борщаговская, 115, г. Киев, 03056, Украина. E-mail: frolov@ geobud.kiev.ua

По результатам проведенных исследований получена зависимость усредненной линейной массы заряда взрывчатого вещества от расстояния между скважинами, которая обеспечивает развитие направленной сети трещин между зарядами контурного ряда при их взрывании. Установлено, что каждому типу конструкции заряда, который характеризуется усредненной линейной массой взрывчатого вещества, соответствует оптимальное значение расстояния между контурными скважинами. Предложена конструкция контурного заряда, в которой взрывчатое вещество размещается в полимерной оболочке равномерно по его длине и удерживается в вертикальном положении по оси скважины.

Ключевые слова: взрыв, скважина, контур, параметр, заряд, порода, уступ.

Стаття надійшла 11.05.2018. 